\title{
Regional estimation of current and future forest biomass
}

\author{
R.A. Mickler ${ }^{\mathrm{a}, *}$, T.S. Earnhardt ${ }^{\mathrm{b}}$, J.A. Moore ${ }^{\mathrm{c}}$ \\ ${ }^{a}$ Mantech Environmental Technology, Inc., 920 Main Campus Drive, Venture Center II Suite 300, Raleigh, NC 27606, USA \\ ${ }^{\mathrm{b}}$ North Carolina State University, 920 Main Campus Drive, Venture Center II Suite 300, Raleigh, NC 27606, USA \\ ${ }^{\mathrm{c}}$ USDA Forest Service, 920 Main Campus Drive, Venture Center II Suite 300, Raleigh, NC 27606, USA
}

"Capsule": Forest net primary production at the regional scale from the PnET model show areas of high and low forest carbon storage potential and their spatial relationship [to other landscape features.]

\begin{abstract}
The 90,674 wildland fires that burned 2.9 million ha at an estimated suppression cost of \$1.6 billion in the United States during the 2000 fire season demonstrated that forest fuel loading has become a hazard to life, property, and ecosystem health as a result of past fire exclusion policies and practices. The fire regime at any given location in these regions is a result of complex interactions between forest biomass, topography, ignitions, and weather. Forest structure and biomass are important aspects in determining current and future fire regimes. Efforts to quantify live and dead forest biomass at the local to regional scale has been hindered by the uncertainty surrounding the measurement and modeling of forest ecosystem processes and fluxes. The interaction of elevated $\mathrm{CO}^{2}$ with climate, soil nutrients, and other forest management factors that affect forest growth and fuel loading will play a major role in determining future forest stand growth and the distribution of species across the southern United States. The use of satellite image analysis has been tested for timely and accurate measurement of spatially explicit land use change and is well suited for use in inventory and monitoring of forest carbon. The incorporation of Landsat Thematic Mapper data coupled with a physiologically based productivity model (PnET), soil water holding capacity, and historic and projected climatic data provides an opportunity to enhance field plot based forest inventory and monitoring methodologies. We use periodic forest inventory data from the USDA Forest Service's Forest Inventory and Analysis (FIA) project to obtain estimates of forest area and type to generate estimates of carbon storage for evergreen, deciduous, and mixed forest classes for use in an assessment of remotely sensed forest cover at the regional scale for the southern United States. The displays of net primary productivity (NPP) generated from the PnET model show areas of high and low forest carbon storage potential and their spatial relationship to other landscape features for the southern United States. At the regional scale, predicted annual NPP in 1992 ranged from 836 to $2181 \mathrm{~g} / \mathrm{m}^{2} /$ year for evergreen forests and $769-2634 \mathrm{~g} / \mathrm{m}^{2} /$ year for deciduous forests with a regional mean for all forest land of $1448 \mathrm{~g} / \mathrm{m}^{2} /$ year. Prediction of annual NPP in 2050 ranged from 913 to $2076 \mathrm{~g} / \mathrm{m}^{2} /$ year for evergreen forest types to $1214-2376 \mathrm{~g} / \mathrm{m}^{2} /$ year for deciduous forest types with a regional mean for all forest land of $1659 \mathrm{~g} / \mathrm{m}^{2} /$ year. The changes in forest productivity from 1992 to 2050 are shown to display potential areas of increased or decreased forest biomass. This methodology addresses the need for spatially quantifying forest carbon in the terrestrial biosphere to assess forest productivity and wildland fire fuels. (C) 2001 Published by Elsevier Science Ltd. All rights reserved.
\end{abstract}

Keywords: Forest carbon; Productivity modelling; Fuel loading; Net primary production

\section{Introduction}

Fire is one of the dominant disturbances in the United States forests. Fire is a primary process that influences the vegetation composition and structure of any given location and helps to shape the landscape mosaic. Forest structure and composition in the past, present, and in the future are influenced by fire regime. Areas burned

\footnotetext{
* Corresponding author. Tel.: + 1-919-515-9490; fax: + 1-919-513-

E-mail address: robert_mickler@ncsu.edu (R.A. Mickler).
} 2978. by prescribed and wild forest fires in North America can exceed 30 million ha per year. Use of prescribed fire is an important forest management activity in the southeastern $(\sim 2$ million ha burned/year) and northwestern United States $(\sim 150,000$ ha burned/year $)$ and in parts of Canada ( $\sim 200,000$ ha burned/year). Fire is used to remove logging slash prior to plantation establishment, reduce hardwood and herbaceous competition in young stands, improve wildlife habitat, and minimize catastrophic wildfire hazard (by fuel reduction) in older stands. Fuel loads tend to vary between 1 and 200 metric $\mathrm{t}$ per ha with fuel consumption efficiency varying 
from 20 to $80 \%$. Burning activity is projected to increase as managers on federal, private, and industrial lands seek to reduce dry fuel accumulation and minimize wildland fire risk. Wildfires can consume even larger areas than prescribed fires and typically have much higher fuel consumption rates per unit area.

If the projected changes in climate are realized during this century, an altered fire regime could have the most immediate and significant impact on forest ecosystems. Recent studies on the interaction of climate change and forest fires suggest that projected increases in atmospheric carbon dioxide, air temperature, and variability in precipitation will increase fire seasonal severity ratings by $10-50 \%$ over most of North America. The area burned in the United States from wildland fire is projected to increase by $25-50 \%$ by the middle of the twenty-first century with most of the increases occurring in Alaska and the southeastern United States (Flannigan et al., 2000).

Predicting wildland fires is difficult, at best. Dry conditions in the southeastern United States extend from the Gulf Coast northward into the Appalachians. Florida's recent drought conditions are expected to continue with $25 \%$ below-normal precipitation forecasts. The state is actually drier now than is was in 1998 when 2214 wildland fires burned nearly 202,000 ha of land. Fire season in Florida was well underway at the start of 2001 and some of the fires have growing very large, such as the "Uncle Joe's Command" fire at 15,378 ha. An above-average fire season is expected in 2001 for Alabama, Georgia, North Carolina, Virginia, and especially Florida. Meeting the wildland fire fuel information needs of land managers in the southeastern United States is critical now and will become increasing important in the future.

The objective of the research described here is to utilize remotely sensed forest cover data linked to a productivity model to determine, evaluate, project, and map forest biomass from 1992 to 2050 in the southeastern United States. This approach was developed with the goal of integrating existing forest inventory data, climate, soil, landcover data, and the Hadley2Sul climate scenario for the southeastern United States was used as input parameters to forest process models to predict, validate, and project forest growth and forest biomass. These projections will assess the impacts of soils, nitrogen deposition, atmospheric carbon dioxide, and variability in temperature and precipitation on forest growth at the local to regional scale for the southeastern United States. Remotely sensed data, field-based industry data, forest modeling techniques, forest growth and physiological parameters, soils, and climate data will be used to improve the measurement, modeling, estimation, and display of net primary production (NPP). The purpose of this paper is to introduce methodologies for linking remotely sensed
Landsat Thematic Mapper land cover, Forest Inventory and Analysis (FIA) inventory data, and a productivity model (PnET) to estimate and spatially display forest productivity with Anderson Level II precision (Anderson et al., 1976) for the southeastern United States.

\section{Materials and methods}

\subsection{Study region}

The study region encompasses 534,523,000 ha in 13 states from the Mid-Atlantic coast west to Texas and Oklahoma. The region represents approximately $24 \%$ of the land area, $60 \%$ of the forest land, $25 \%$ of the agricultural land for the entire United States. In 1992, forest land-land at least $10 \%$ stocked by forest trees regardless of size - covered $211,838,000$ ha or about $40 \%$ of the total land area in the region (Powell et al., 1993).

The southern United States contains 10 geomorphic regions and a diversity of climates, soil characteristics, and topography. This diverse environment results in a corresponding diversity of tree species and forest types, including southern yellow pines, mixed pine-hardwoods, upland and bottomland hardwoods, and tropical hardwoods in Florida. Across much of the region, pine stands represent a transitional stage in natural succession to hardwood forest types. Mixed pine-hardwood stands are typically composed of $50 \%$ or more oak and other hardwoods and $25-50 \%$ pine.

The southern United States produces over $50 \%$ of commercial timber harvests for the nation. Most of the timberland in the South is in non-industrial private and forestry industry ownership. In 1992, private citizens, farmers, and the forest industry owned $90 \%$ of southern timberland. Non-industrial private ownership includes large numbers of small parcels and a smaller number of large tracts. This ownership group is found near urbanizing areas, dispersed among cultivate lands, and in remote areas. Changing ownership and differing management objectives affect land cover and land use within the region.

\subsection{Forest inventory data}

The primary source of forest land area, growth, and harvest estimates is the field sampling inventory data reported by the FIA Unit of the Forest Service Southern Research Station (Reams and Van Deusen, 1999). Since 1930, forested points have been visited during a five- to 10-year state survey cycle. Prior to 1997, two states were inventoried concurrently and required 2 years to complete the field surveys in each state. FIA reports on the status and trends in forest area and 
location; in the species, size, and health of trees; in total tree growth, mortality, and removals by harvest; in wood production and utilization rates by various products; and in forest land ownership. Recent enhancements in the FIA program include a partial sampling of field plots annually and additional information relating to tree crown condition, lichen community composition, soils, ozone indicator plants, complete vegetative diversity, and coarse woody debris.

The FIA program consists of a national core program that can be enhanced at the regional, state or local level to address special interests. The national core consists of three phases. Phase one is a remote sensing phase aimed at classifying the land into forest and non-forest and taking spatial measurements such as fragmentation, urbanization, and distance variables. This phase has historically been done using aerial photography, but is changing to a system based on satellite imagery. Phase 2 consists of a set of field sample locations distributed across the landscape with approximately 0.4 ha sample locations every 2402 ha. During the second phase, field crews visit forested points to confirm classification and estimate tree- and stand-level attributes. FIA estimates forest area based on a double sampling estimate that uses either photo points or classified pixels and ground plots (Reams, 1999). Phase 3 consists of a subset of the phase two plots which are visited during the growing season in order to collect an extended suite of ecological data including full vegetation inventory, tree and crown condition, soil data, lichen diversity, coarse woody debris, and ozone damage.

FIA data for the most recent field surveys (spanning 1988-1995) for the southern 13 states were obtained from the Forest Service Eastwide Data Base (EWDB) (http://srsfia.usfs.msstate.edu/scripts/ew.htm). This database was developed to provide users with as much FIA field plot data as possible in a manner consistent among states. The TYPCUR records indicated the predominant forest type of the field plot area. The number of acres that the plot represents was determined from the EXPACR records. Forest type groups and forest type names were grouped into three forest classes (evergreen, deciduous, and mixed) that corresponded to Anderson Level II forest classes for each state. The area for each forest class was summarized and totaled for each state (Table 1).

\subsection{Remotely sensed forest classification}

Forest cover mapping Using space borne sensors has been a goal of forest managers since the launch of Landsat-1 in 1972. The enhanced spatial, spectral, and radiometric resolution available with the launch of Landsat-4 and subsequent Landsat satellites has demonstrated the application of the Thematic Mapper sensor in discerning forest cover classification at
Anderson Level II and III precision. One of the projects sponsored by the MultiResolution Land Characteristics (MRLC) Consortium produced land-cover data for the conterminous United States (Vogelmann et al., 1998). Land cover was mapped using general land cover classes. For example, forest is classified as either, deciduous, evergreen or mixed. Land-cover classification was based on MRLC's Landsat 5 Thematic Mapper (TM) satellite data archive and a host of ancillary sources.

MRLC project requirements dictated that standardized processing be applied to all scenes. Noise removal and geometric registration with terrain correction were performed according to documented methods.

The Landsat Thematic Mapper data used for this project was preprocessed following the procedures described by MRLC (http://edc.usgs.gov/glis/hyper/ guide/mrlc\#mrlc4) for the National Land Cover Data set (NLCD). The NLCD-selected TM scenes consist of data acquired between 1990 and 1994. Landsat Thematic Mapper and ancillary data in the NLCD set was acquired for the 13 southeastern United States states from MRLC (http://www.epa.gov/mrlc/nlcd.html). Individual state flat land cover files were unzipped and imported into ERDAS IMAGINE ${ }^{\circledR}$. Image data was projected to Albers projection, NAD83 datum, GRS1980 spheroid, and units of meters. Individual state images were mosaicked to produce one regional image file. Forest area was displayed and summarized for NLCD land cover classes: deciduous forest (class 41), evergreen forest (class 42), and mixed forest (class 43). The deciduous forest class was supplemented with woody wetland (class 91) for a new combined deciduous forest class.

\subsection{Climate scenarios}

To predict forest growth, historic and future monthly climate data were used as model inputs. One of the first objectives for VEMAP Phase 2 dataset development was the creation of an historic $\sim 100$-year gridded monthly and daily time series of climate for the conterminous United States that includes realistic interannual variability (Kittel et al., 2000). A beta-version of the VEMAP2 1895-1993 multivariate climate dataset was completed in early 1998 (Kittel et al., 1997) and subsequently publicly released as a final version (http:// www.cgd.ucar.

edu/vemap/datasets.html). The historical dataset has: (1) daily and monthly versions, (2) physical consistency among variables on a daily basis, (3) consistency between climate and topography, and (4) input variables minimum and maximum temperature, precipitation, vapor pressure, and solar radiation. Two forest productivity model experiments were run. First, a forest productivity model was run with historic climate data from 1895 to 1993 to simulate current forest productivity. Second, this same model was integrated 
Table 1

Comparison of FIA and Landsat Thematic Mapper forest land estimates of evergreen, deciduous, and mixed forest types (hectares)

\begin{tabular}{|c|c|c|c|c|c|}
\hline State & & Evergreen & Deciduous & Mixed & Total forest land \\
\hline \multirow[t]{3}{*}{ Alabama } & FIA & $3,013,748.20$ & $4,014,086.71$ & $1,829,891.42$ & $8,857,726.33$ \\
\hline & $\mathrm{TM}$ & $2,656,810.62$ & $3,966,984.79$ & $3,244,051.93$ & $9,867,847.34$ \\
\hline & $\%$ Difference & $13.43 \%$ & $1.19 \%$ & $-43.59 \%$ & $-10.24 \%$ \\
\hline \multirow[t]{3}{*}{ Arkansas } & FIA & $2,078,078.67$ & $4,208,627.04$ & $1,299,747.81$ & $7,586,453.51$ \\
\hline & $\mathrm{TM}$ & $1,898,427.19$ & $4,466,085.26$ & $1,604,988.64$ & $7,969,501.09$ \\
\hline & $\%$ Difference & $9.46 \%$ & $-5.76 \%$ & $-19.02 \%$ & $-4.81 \%$ \\
\hline \multirow[t]{3}{*}{ Florida } & FIA & $3,106,246.70$ & $2,434,685.21$ & $619,696.80$ & $6,160,628.71$ \\
\hline & $\mathrm{TM}$ & $2,943,409.96$ & $3,366,348.34$ & $365,796.58$ & $6,675554.88$ \\
\hline & \%Difference & $5.53 \%$ & $-27.68 \%$ & $69.41 \%$ & $-7.71 \%$ \\
\hline \multirow[t]{3}{*}{ Georgia } & FIA & $4,564,041.78$ & $4,077,393.92$ & $1,541,863.54$ & $10,183,299.24$ \\
\hline & $\mathrm{TM}$ & $3,609,443.82$ & $4,579,154.81$ & $1,815,506.82$ & $10,004,105.45$ \\
\hline & $\%$ Difference & $26.45 \%$ & $-20.96 \%$ & $-15.07 \%$ & $1.79 \%$ \\
\hline \multirow[t]{3}{*}{ Kentucky } & FIA & $287,103.17$ & $4,422,140.71$ & $359,951.68$ & $5,069,195.56$ \\
\hline & $\mathrm{TM}$ & $300,075.41$ & $5,302,605.26$ & $749,075.64$ & $6,351,756.31$ \\
\hline & $\%$ Difference & $-4.32 \%$ & $-16.60 \%$ & $-51.95 \%$ & $-20.19 \%$ \\
\hline \multirow[t]{3}{*}{ Louisiana } & FIA & $2,026,126.98$ & $2,759,868.62$ & $763,481.28$ & $5,549,476.88$ \\
\hline & $\mathrm{TM}$ & $1,912,348.42$ & $2,2313,190.89$ & $1,158,902.16$ & $5,384,441.47$ \\
\hline & $\%$ Difference & $5.95 \%$ & $19.31 \%$ & $-34.12 \%$ & $3.07 \%$ \\
\hline \multirow[t]{3}{*}{ Mississippi } & FIA & $2,327,369.51$ & $3,863,063.59$ & $1,305,056.90$ & $7,495,489.99$ \\
\hline & $\mathrm{TM}$ & $2,405,419.06$ & $3,439,718.09$ & $1,707,900.55$ & $7,553,037.70$ \\
\hline & \%Difference & $-3.24 \%$ & $12.31 \%$ & $-23.59 \%$ & $-0.76 \%$ \\
\hline \multirow[t]{3}{*}{ North Carolina } & FIA & $2,610,522.52$ & $4,090,120.92$ & $1,061,366.93$ & $7,762,010.38$ \\
\hline & $\mathrm{TM}$ & $2,458,068.84$ & $4,841,958.55$ & $1,474,274.74$ & $8,774,302.13$ \\
\hline & $\%$ Difference & $6.20 \%$ & $-15.53 \%$ & $-28.01 \%$ & $-11.54 \%$ \\
\hline \multirow[t]{3}{*}{ Oklahoma } & FIA & $452,852.44$ & $1,445,420.15$ & $291,652.66$ & $2,189,925.26$ \\
\hline & $\mathrm{TM}$ & $374,780.63$ & $3,077,523.23$ & $444,872.42$ & $3,897,176.28$ \\
\hline & $\%$ Difference & $20.83 \%$ & $-53.03 \%$ & $-34.44 \%$ & $-43.81 \%$ \\
\hline \multirow[t]{3}{*}{ South Carolina } & FIA & $2,297,097.30$ & $2,088,095.48$ & $784,276.53$ & $5,169,469.31$ \\
\hline & $\mathrm{TM}$ & $2,100,527.87$ & $2,305,946.99$ & $902,006.85$ & $5,308,481.72$ \\
\hline & \%Difference & $9.36 \%$ & $-9.45 \%$ & $-13.05 \%$ & $-2.62 \%$ \\
\hline \multirow[t]{3}{*}{ Tennessee } & FIA & $565,658.13$ & $4,156,225.33$ & $644,074.33$ & $5,365,957.80$ \\
\hline & $\mathrm{TM}$ & $814,756.34$ & $4,816,341.86$ & $1,274,723.58$ & $6,905,821.78$ \\
\hline & $\%$ Difference & $-30.57 \%$ & $-13.71 \%$ & $-49.47 \%$ & $-22.30 \%$ \\
\hline \multirow[t]{3}{*}{ Texas } & FIA & $1,755,492.95$ & $2,030,708.03$ & $1,027,633.44$ & $4,813,834.42$ \\
\hline & $\mathrm{TM}$ & $3,891,105.97$ & $1,159,873.41$ & $1,863,583.64$ & $6,914,563.02$ \\
\hline & $\%$ Difference & $-54.88 \%$ & $75.08 \%$ & $-44.86 \%$ & $-30.38 \%$ \\
\hline \multirow[t]{3}{*}{ Virginia } & FIA & $1,395,965.78$ & $4,195,054.24$ & $795,089.36$ & $6,386,109.38$ \\
\hline & $\mathrm{TM}$ & $848,911.92$ & $4,466,125.73$ & $1,540,764.82$ & $6,855,802.47$ \\
\hline & \%Difference & $64.44 \%$ & $-6.07 \%$ & $-48.40 \%$ & $-6.85 \%$ \\
\hline \multirow{3}{*}{ Southeastern United States } & FIA & $26,480,304.13$ & $43,785,489.97$ & $12,323,782.67$ & $82,589,576.76$ \\
\hline & $\mathrm{TM}$ & $26,214,086.05$ & $48,101,857.23$ & $18,146,448.36$ & $92,462,391.64$ \\
\hline & $\%$ Difference & $1.02 \%$ & $-8.97 \%$ & $-32.09 \%$ & $-10.68 \%$ \\
\hline
\end{tabular}

forward Using the output from the Hadley2Sul scenario (http://www.met-office.gov.uk/research/hadleycentre/ index.html) Using climate results translated into the
VEMAP grid for the simulated period 1993-2100. Forest area for evergreen, deciduous, and mixed forest is summarized in Table 1. 


\subsection{Soil data}

The State soil Geographic Data Base (STATSGO) was developed by the United States Natural Resources conservation Service to store and distribute soil-survey information for United States lands. STATSGO data contain physical and chemical soil properties for $\sim 18,000$ soil series (Soil Conservation Service, 1991). STATSGO maps were compiled by generalizing more detailed soil-survey maps into soil associations at a scale $(1: 250,000)$ more appropriate for regional analysis. Soil water holding capacity (SWHC) derived from CONUSSoil dataset (Miller and White, 1998) is the only soils parameter required by PnET. The SWHC data was converted into the $0.5 \times 0.5^{\circ}$ grid via area-weighted averaging of the CONUS soil series SWHC polygons.

\subsection{Forest productivity modeling}

We generated regional estimates of current and future forest net primary production with the PnET model. PnET is a forest process model developed to predict forest productivity and hydrology across a range of climates and site conditions (Aber and Federer, 1992; Aber et al., 1995; Ollinger et al., 1998; McNulty et al., 1994, 2000). PnET is a physiologically based, monthly time step model that has been used to predict changes in forest carbon, water, and nutrient cycling across the eastern United States. PnET uses vegetation, soil, and climate parameters to predict forest growth under historic, current, and future environmental conditions. Empirical relationships between maximum photosynthesis rates and foliar nitrogen concentration are utilized by PnET to calculate the maximum leaf area a site can support. Photosynthesis is then adjusted with corresponding climate, site, and soil constraints.

Predicted NPP equals total gross photosynthesis minus growth and maintenance respiration for leaf, wood, and root compartments. PnET calculates respiration as a function of the current and previous month's minimum and maximum air temperature. Changes in water availability and plant water demand also place limitations on leaf area produced, so as vapor pressure deficit and air temperature increase above optimal levels, total leaf area decreases. Reduced leaf area decreases total carbon fixation and alters ecosystem hydrology. The gridded databases of minimum and maximum air temperature, relative humidity, and precipitation were used to calculate average monthly solar radiation. Solar radiation values were then combined with monthly maximum and minimum air temperature and total monthly precipitation as input for PnET. Predictions of forest biomass from PnET have been well correlated with average annual basal area growth measured at sites across the region (McNulty et al., 1998). Forest biomass predictions for 1992 were estimated
Using a mean of NPP for the years 1991-1993 from the PnET model. Projections of forest NPP in 2050 are a decadal mean of NPP for the period 2046-2055. The decadal mean of NPP was reported to better represent growth trends about 2050 rather than highlight a single year's growth. Forest NPP is displayed with the Landsat TM forest type map, refining the spatial resolution of the biomass predictions to $30 \mathrm{~m}$.

\section{Results and discussion}

\subsection{Landsat and FIA forest area estimates}

FIA statistics of forest land acreages for evergreen, deciduous, and mixed classes were summarized for individual states and the region from information compiled for the 1992 Resource Planning Act Assessment, reported by Powell et al. (1993). FIA statistics for forest land were aggregated into evergreen, deciduous, and mixed forest cover types and the areas were summarized for each forest cover type (Table 1). The areas were compared with calibrated Landsat Thematic Mapper classifications in the NLCD at the state and regional scales (Table 1).

Because the FIA inventory defines forest classes at the species and forest type group level and the NLCD defines forest classes at Anderson Level II, it is difficult to make direct comparisons of more specific forest cover types. Comparison difficulties arose in estimated areas for the mixed forest cover type. For example, FIA would classify a field plot as mixed forest type group only if by visual inspection the field crew determines that deciduous or conifer tree species comprise $25-50 \%$ of the stocking on the plot. Data from 0.4 ha field plots within each county are used in conjunction with an expansion factor to estimating forest area to the county and state spatial scales. In contrast the NLCD classifies mixed forest types through image analysis techniques using leaf-on and leaf-off imagery, baseline clustering Using unsupervised classification image analysis, and cluster interpretation and labeling using aerial photography. Forest cover type and area were determined from spectral reflectance characteristics from data collected from a consistent and seamless $30-\mathrm{m}$ grid. The states of Texas and Oklahoma posed additional comparison difficulties. The FIA inventories used for this study included data for only 43 of 254 Texas counties and 18 of 77 Oklahoma counties. Counties were excluded from the inventory if they were not classified as having forest land (land at least 10\% stocked by forest trees of any size or formerly covered having such tree cover) or had insufficient forest area to warrant an inventory of forest resources.

Finally, it should be noted that there is temporal variability in the two data sets. Due to the periodic 
nature of the FIA forest inventory process the inventories for the 13 southeastern states span the time period of 1988-1995. Acquiring the data for a seamless Landsat data coverage for the region posed different data acquisition requirements. The NLCD set required cloud-free Landsat TM scenes for two time periods (leaf-on and leaf-off) for the continental United States. Landsat TM data was acquired from 1990 to 1994 in order to meet the spectral information and geographic coverage goal of the MRLC. The field plot based FIA data and the remotely sensed NLCD set represent the best available regional-scale forest land cover data sets available for comparison for this time period.

At the regional scale, there was close agreement in evergreen, deciduous, and total forest land cover area. The differences between the two data set was $-10.68 \%$ for total forest land, $+1.02 \%$ for evergreen forests, $-8.97 \%$ for deciduous forests, and $-32.09 \%$ for mixed forests, with TM data as the standard or base (Table 1). At the state level, agreement for forest land area ranged from $+0.76 \%$ for Mississippi to $-43.81 \%$ for Oklahoma (due to the previously discussed partial FIA sampling for Oklahoma). The sampling error for FIA estimates of timberland ranged from 0.2 to $0.6 \%$ at the state level (http://srsfia.usfs.msstate.edu). User's accuracy for the NLCD set for the southeastern United States. (Region 4) was 56, 64 and $85 \%$ for evergreen, deciduous and mixed forest land cover, respectively (http://edcwww.cr.usgs.gov/programs/lccp/accuracy/ appendix.html).

\subsection{Annual net primary production}

The pattern of annual NPP for forest lands in 1992 for the southeastern U.S. is shown in Fig. 1. The spatial patterns of forest production shows that the highest NPP in the region for evergreen, deciduous, and mixed forest types is along the Gulf Coastal Plain. Annual maximum NPP ranged from $2181 \mathrm{~g} / \mathrm{m}^{2} /$ year for evergreen forests to $2634 \mathrm{~g} / \mathrm{m}^{2} /$ year for deciduous forests (Table 2). The lowest values of annual NPP for all forest types were found in Virginia, which indicates that PnET estimates of NPP may be more sensitive to the combined influence of minimum air temperature and solar radiation rather than the extremes in temperature and precipitation found along the interface of rangeland and forest ecoregions in western Texas and Oklahoma. At the regional scale, mean annual NPP ranged from $1406 \mathrm{~g} / \mathrm{m}^{2} /$ year for evergreen forests to $1490 \mathrm{~g} / \mathrm{m}^{2} /$ year for deciduous forests with a regional mean for all forest land of $1448 \mathrm{~g} / \mathrm{m}^{2} /$ year. The results show that highest productivity of evergreen, deciduous, and mixed forests are located along the coastal plain, piedmont, and mountain physiographic provinces, respectively for southeastern states. In contrast, Ollinger et al. (1998) reported NPP ranging from 700 to 1450 $\mathrm{g} / \mathrm{m}^{2} /$ year with a regional mean of $1084 \mathrm{~g} / \mathrm{m}^{2} /$ year using the PnET model for northeastern United States forests.

Prediction of annual NPP in 2050 ranged 913-2076 g/ $\mathrm{m}^{2} /$ year for evergreen forest types to $1214-2376 \mathrm{~g} / \mathrm{m}^{2} /$ year

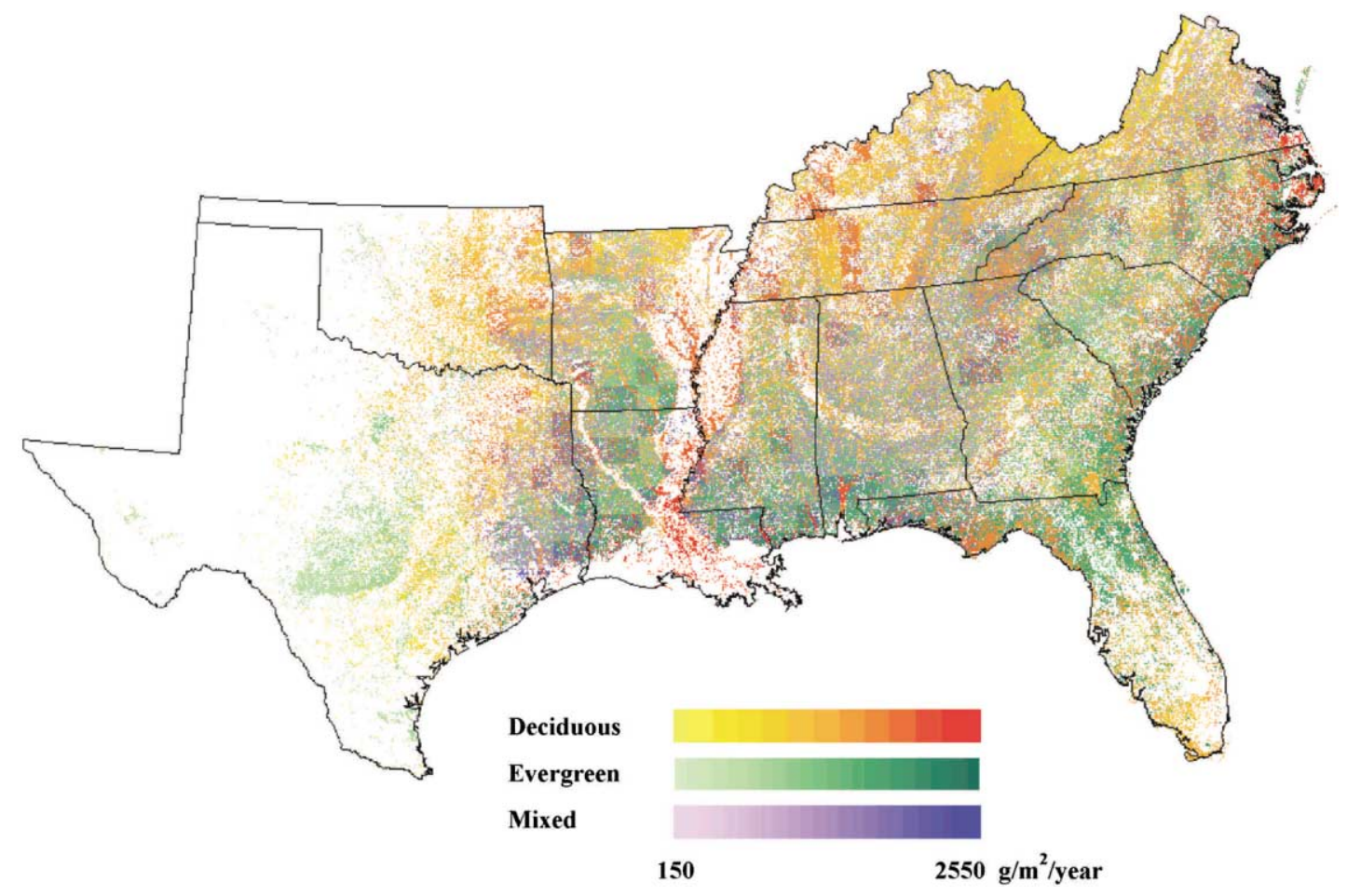

Fig. 1. PnET model estimation of annual net primary production for evergreen, deciduous, and mixed forest cover types for the southeastern United States (1992). 
Table 2

Current and 2050 minimum, maximum, and average net primary production $\left(\mathrm{g} / \mathrm{m}^{2} /\right.$ year) for evergreen, deciduous, and mixed forest types

\begin{tabular}{|c|c|c|c|c|c|c|c|}
\hline \multirow[t]{2}{*}{ State } & \multirow[t]{2}{*}{ Forest type } & \multicolumn{3}{|l|}{1992} & \multicolumn{3}{|l|}{2050} \\
\hline & & Min. NPP & Max. NPP & Ave. NPP & Min. NPP & Max. NPP & Ave. NPP \\
\hline \multirow[t]{3}{*}{ Alabama } & Evergreen & 1080 & 1796 & 1327 & 1261 & 1656 & 1410 \\
\hline & Deciduous & 1046 & 2186 & 1376 & 1642 & 2239 & 1869 \\
\hline & Mixed & 1063 & 1991 & 1351 & 1482 & 1856 & 1639 \\
\hline \multirow[t]{3}{*}{ Arkansas } & Evergreen & 965 & 1623 & 1265 & 937 & 1395 & 1692 \\
\hline & Deciduous & 884 & 2148 & 1453 & 1431 & 2015 & 1207 \\
\hline & Mixed & 925 & 1886 & 1359 & 1190 & 1686 & 1449 \\
\hline \multirow[t]{3}{*}{ Florida } & Evergreen & 1214 & 2116 & 1756 & 1184 & 2076 & 1559 \\
\hline & Deciduous & 1009 & 2186 & 1494 & 1429 & 2375 & 2108 \\
\hline & Mixed & 1112 & 2002 & 1625 & 1396 & 2151 & 1834 \\
\hline \multirow[t]{3}{*}{ Georgia } & Evergreen & 1121 & 1958 & 1420 & 1138 & 1811 & 1405 \\
\hline & Deciduous & 1009 & 1951 & 1421 & 1635 & 2328 & 1965 \\
\hline & Mixed & 1112 & 1932 & 1421 & 1402 & 2069 & 1685 \\
\hline \multirow[t]{3}{*}{ Kentucky } & Evergreen & 1040 & 1550 & 1230 & 1146 & 1506 & 1313 \\
\hline & Deciduous & 902 & 1981 & 1269 & 1607 & 2092 & 1846 \\
\hline & Mixed & 973 & 1725 & 1250 & 1436 & 1764 & 1580 \\
\hline \multirow[t]{3}{*}{ Louisiana } & Evergreen & 1190 & 2181 & 1694 & 1154 & 2009 & 1476 \\
\hline & Deciduous & 1267 & 2634 & 2047 & 1502 & 2376 & 2014 \\
\hline & Mixed & 1230 & 2402 & 1871 & 1328 & 2193 & 1745 \\
\hline \multirow[t]{3}{*}{ Mississippi } & Evergreen & 1112 & 1952 & 1463 & 1275 & 1718 & 1392 \\
\hline & Deciduous & 1198 & 2531 & 1646 & 1702 & 2274 & 1903 \\
\hline & Mixed & 1668 & 2241 & 1555 & 1494 & 1996 & 1648 \\
\hline \multirow{3}{*}{ North Carolina } & Evergreen & 1166 & 1910 & 1483 & 1463 & 1801 & 1598 \\
\hline & Deciduous & 1131 & 2390 & 1611 & 1746 & 2360 & 2097 \\
\hline & Mixed & 1163 & 2150 & 1547 & 1606 & 2069 & 1847 \\
\hline \multirow[t]{3}{*}{ Oklahoma } & Evergreen & 976 & 1428 & 1181 & 996 & 1259 & 1116 \\
\hline & Deciduous & 1104 & 1764 & 1367 & 1257 & 1776 & 1505 \\
\hline & Mixed & 1070 & 1571 & 1274 & 1134 & 1485 & 1311 \\
\hline \multirow[t]{3}{*}{ South Carolina } & Evergreen & 1142 & 1924 & 1419 & 1288 & 1822 & 1517 \\
\hline & Deciduous & 1111 & 2082 & 1464 & 1684 & 2376 & 2014 \\
\hline & Mixed & 1132 & 1992 & 1442 & 1535 & 2099 & 1765 \\
\hline \multirow[t]{3}{*}{ Tennessee } & Evergreen & 1108 & 1696 & 1322 & 1250 & 1667 & 1409 \\
\hline & Deciduous & 1154 & 2148 & 1420 & 1711 & 2174 & 1905 \\
\hline & Mixed & 1140 & 1886 & 1371 & 1485 & 1884 & 1657 \\
\hline \multirow[t]{3}{*}{ Texas } & Evergreen & 997 & 2062 & 1396 & 913 & 1866 & 1232 \\
\hline & Deciduous & 1022 & 2459 & 1529 & 1214 & 2225 & 1609 \\
\hline & Mixed & 1055 & 2260 & 1463 & 1064 & 2046 & 1421 \\
\hline \multirow[t]{3}{*}{ Virginia } & Evergreen & 836 & 1801 & 1249 & 926 & 1691 & 1451 \\
\hline & Deciduous & 769 & 2337 & 1291 & 1378 & 2210 & 1863 \\
\hline & Mixed & 802 & 2069 & 1270 & 1220 & 1951 & 1657 \\
\hline \multirow[t]{3}{*}{ Southeastern United States } & Evergreen & 836 & 2181 & 1406 & 913 & 2076 & 1410 \\
\hline & Deciduous & 769 & 2634 & 1490 & 1214 & 2376 & 1908 \\
\hline & Mixed & 802 & 2402 & 1448 & 1064 & 2193 & 1659 \\
\hline
\end{tabular}




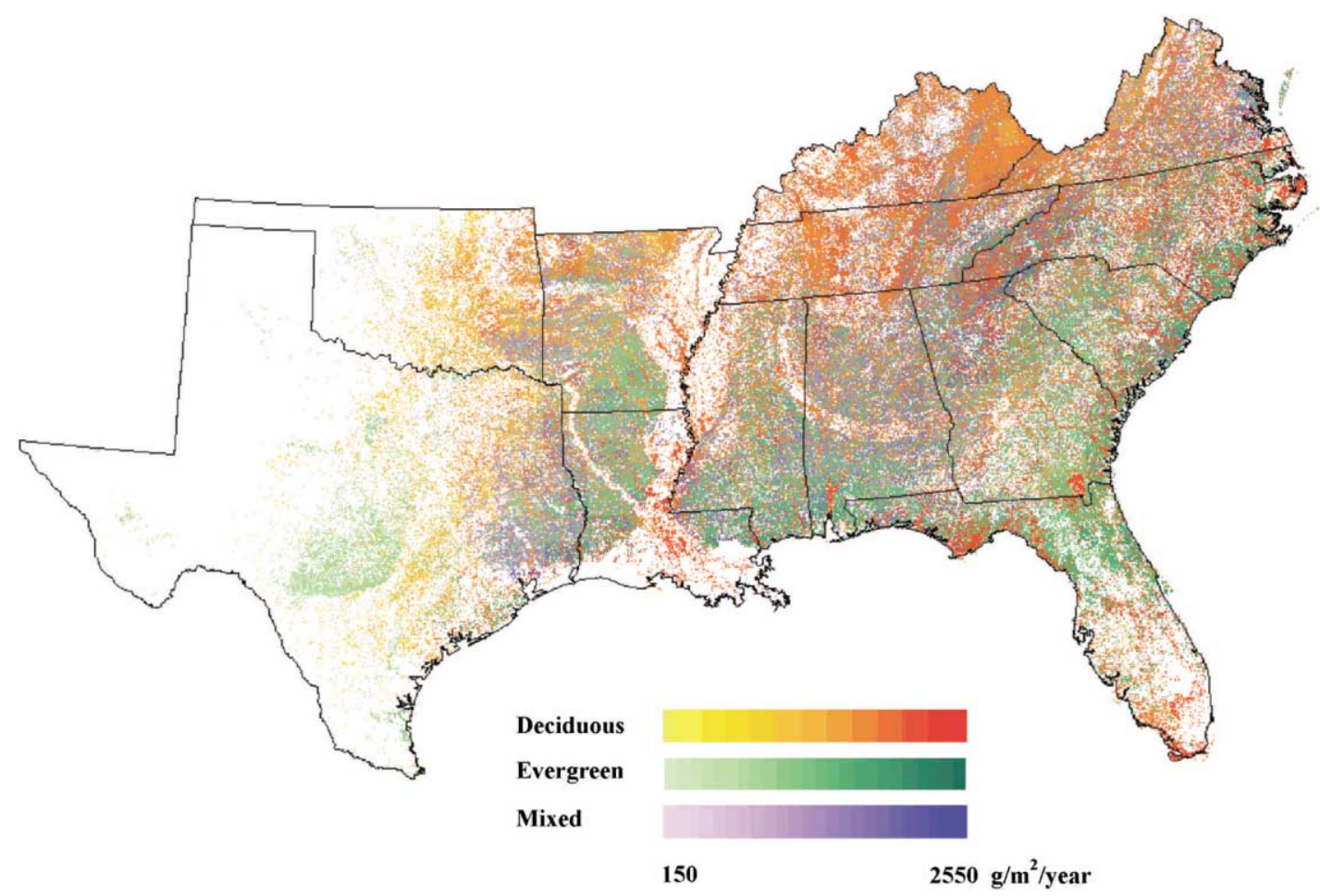

Fig. 2. PnET model estimation of annual net primary production for evergreen, deciduous, and mixed forest cover types for the southeastern United States (2050).

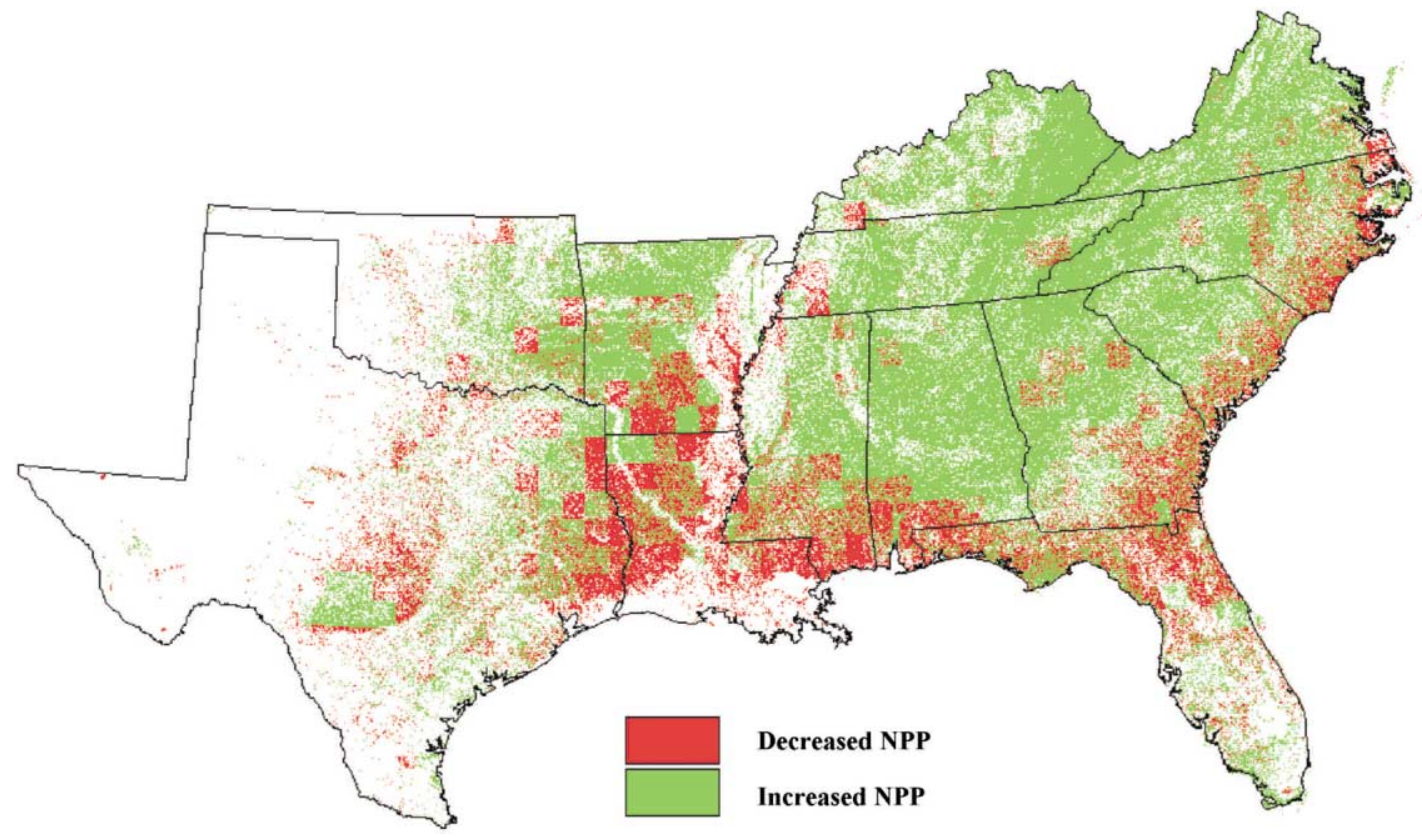

Fig. 3. Changes in net primary production for evergreen, deciduous, and mixed forest cover types from 1992 to 2050 for the southeastern United States.

for deciduous forest types (Table 2). The spatial pattern of NPP is shown in Fig. 2. The lowest growth rates for evergreen and deciduous forests were found in Texas due to increases in air temperature associated with the climate projection from the Hadley2Sul scenario. The change in
NPP from 1992 to 2050 is shown in Fig. 3. At the regional scale, mean NPP increases for all forest types and ranged from 1410 to $1908 \mathrm{~g} / \mathrm{m}^{2} /$ year. Within the region, NPP generally decreases along the Coastal Plain of the East and Gulf coasts. 


\section{Conclusions}

The future composition of forest ecosystems due to the effects of global climate change and socio-economic responses to that change can only be hypothesized upon. The reported analysis provides an estimate of forest production for 1992 and 2050 for the southeastern United States using an uncalibrated model of forest carbon balance and forest cover from Landsat TM data. Future trends in climate suggest temperature limitations will be a contributing factor in lowering future forest productivity along the East and Gulf Coastal Plains, especially for evergreen forests. Forest productivity for deciduous and mixed forest types is predicted to increase in the future for the Piedmont and Mountain physiographic provinces. Productivity increases for these two forest types contribute to a general trend of increased forest productivity at the regional scale, assuming a warmer and wetter climate projected under the Hadley2Sul scenario.

The use of field plot-based inventories and remotely sensed data will enhance our ability to conduct change detection analyses for forest type and area. Historically, the USDA Forest Service FIA has produced area estimates of forest type from field plot sampling techniques. Remotely sensed data and image processing techniques provide the ability to assess changes in forest structure across spatial and temporal scales for use by local, state, and regional land managers. The incorporation of techniques and methods from traditional forest inventory with high-resolution imagery is providing unique solutions to the persistent problem of allocation of resources for an annual forest inventory at the county to regional scale. The relationships established between image spectral responses and field plot based forest inventories will enable the merging of forest growth and inventory parameters with detailed spatial information. Linking this information with forest growth simulation models provides estimates of future forest productivity at large spatial scales under predicted climate and forest management activities.

The climate change scenario and forest productivity model used in this study suggests increases in forest NPP of $15-28 \%$ for the deciduous and mixed forests of the region while evergreen productivity remains constant at the regional scale. The impact of climate change on fire regimes in the southern United States. will likely be altered as the Piedmont and Mountain physiographic provinces increase productivity and the evergreen forests of the Coastal Plain decrease productivity. The management of wildland fuel type and load could be used in reducing risk of wildland fire to suburban and urban population centers. At the regional scale, however, wildland fire fuel management would likely not be financially feasible. This study suggests that the model- ing of forest productivity to estimate forest biomass at the regional scale could be used by forest managers to balance climate induced changes in forest NPP, fuel loads, and fire regime with their goal of protecting people and resources.

\section{Acknowledgements}

The USDA Forest Service Southern Research Station's Southern Global Change Program and Research Work Unit SRS-4852 provided support for this research. The research reported in this paper has not been subject to policy review by the USDA Forest Service and should not be construed to represent the policies of the agency. This paper was presented at the USDA Forest Service Southern Global Change Program sponsored Advances in Terrestrial Ecosystem: Carbon Inventory, Measurements, and Monitoring Conference held 3-5 October 2000 in Raleigh, North Carolina.

\section{References}

Aber, J.D., Federer, C.A., 1992. A generalized, lumped-parameter model of photosynthesis, evapotranspiration, and net primary production in temperate and boreal forest ecosystems. Oecologia 92, 463-474.

Aber, J.D., Ollinger, S.V., Federer, C.A., Reich, P.B., Goulden, M.L., Kicklighter, D.W., Melillo, J.M., Lathrop, R.G., 1995. Predicting the effects of climate change on water yield and forest production in the Northeastern US. Climate Research 5, 207-222.

Anderson, J.R., Hardy, E.E., Roach, J.T., Witmer, R.E., 1976. A Land Use and Land Cover Classification System for Use with Remote Sensor Data (US Geological Survey Professional Paper 964). Washington, DC.

Flannigan, M.D., Stocks, B.J., Wotton, B.M., 2000. Climate change and forest fires. The Science of the Total Environment 262, 221-229.

Kittel, T.G.F., Royle, J.A., Daly, C., Rosenbloom, N.A., Gibson, W.P., Fisher, H.H., Schimel, D.S., Berliner, L.M., VEMAP2 Participants, 1997. A gridded historical (1895-1993) bioclimate dataset for the conterminous United States. In: Proceedings of the 10th Conference on Applied Climatology, 20-24 October 1997, Reno, NV. American Meteorological Society, Boston., pp. 219-222.

Kittel, T.G.F., Rosenbloom, N.A., Kaufman, C., Royle, J.A., Daly, C., Fisher, H.H., Gibson, W.P., Aulenbach, S., McKeown, R., Schimel, D.S., VEMAP 2 Participants, 2000. VEMAP 2: US Monthly Climate, 1895-1993, Version 2, [Available: http:// www.daac.ornl.gov/].

McNulty, S.G., Vose, J.M., Swank, W.T., 1998. Predictions and projections of pine productivity and hydrology in response to climate change across the southern United States. In: Mickler, R.A., Fox, S. (Eds.), The Productivity and Sustainability of Southern Forest Ecosystems in a Changing Environment. Springer-Verlag, New York, NY, pp. 391-406.

McNulty, S.G., Vose, J.M., Swank, J.D., Aber, J.D., Federer, C.A., 1994. Regional-scale forest ecosystem modeling database development, model predictions and validation using a geographic information system. Climate Research 4, 223-231.

McNulty, S.G., Moore, J.A., Iverson, L., Prasad, A., Abt, R., Smith, G., Sun, G., Gavazzi, M., Bartlett, J., Murray, B., Mickler, R.A., Aber, J.D., 2000. Application of linked regional 
scale growth, biogeography and economic models for southeastern United States pine forests. World Resource Review 12, 298-320.

Miller, D.A., White, R.A., 1998. A Conterminous United States Multi-Layer Soil Characteristics Data Set for Regional Climate and Hydrology Modeling; Earth Interactions [Available: at http:// earthinteractions.org].

Olinger, S.V., Aber, J.D., Federer, C.A., 1998. Estimating regional forest productivity and water yield using an ecosystem model linked to a GIS. Landscape Ecology 13, 323-334.

Powell, D.S., Faulkner, J.L., Darr, D.R., Zhu, Z., MacCleery, D.W., 1993. Forest Resources of the United States; USDA Forest Service (General Technical Report RM-234). Fort Collins, CO.

Reams, G.A., 1999. SAFIS area estimation techniques. In: McRobert,
R.E., Reams, G.A., Van Deusen, P.C. (Eds.), Proceedings of the First Annual Forest Inventory and Analysis Symposium, November 2-3 1999. UDSA Forest Service, North Central Research Station, Tech. Report NC-213, St Paul, MN, pp.32-36.

Reams, G.A., Van Deusen, P.C., 1999. The southern annual forest inventory system. J. Agric. Bio. Environ. Stat. 4 (4), 346-360.

Soil Conservation Service, 1991. State Soil Geographic Data Base (STATSGO) Data Users Guide. Miscellaneous Publication 1492. US Department of Agriculture, Soil Conservation Service, Washington, DC.

Vogelmann, J.E., Sohl, T., Howard, S.M., Shaw, D.M., 1998. Regional land cover characterization using Landsat Thematic Mapper data and ancillary data sources. Environ. Monitoring and Assessment 51, 415-428. 